\title{
Оцінка ефективності селективної артеріальної емболізаціі у хворих з доброякісною гіперплазією передміхурової залози та високим операційним ризиком
}

\author{
С. В. Головко ${ }^{1}$, О. Ф. Савицький ${ }^{2}$ А. А. Кобірніченко ${ }^{1}$, А. В. Лисак ${ }^{1}$, І. Л. Троіцький ${ }^{1}$ \\ ${ }^{1}$ Національний військово-медичний клінічний центр «Головний військовий клінічний госпіталь», м. Київ, \\ ${ }^{2}$ Українська військово-медична академія, м. Київ
}

\section{Estimation of efficacy of selective arterial embolization in patients with benign prostatic hyperplasia and high operation risk}

\author{
S. V. Golovko' ${ }^{1}$ O. F. Savitsky ${ }^{2}$, A. A. Kobirnichenko ${ }^{1}$, A. V. Lysak ${ }^{1}$, I. L. Troitskiy ${ }^{1}$ \\ ${ }^{1}$ National Military-Medical Clinical Centre «Central Military Clinical Hospital», Kyiv, \\ ${ }^{2}$ Ukrainian Military-Medical Academy, Kyiv
}

\section{Реферат}

Мета. Покращити результати хірургічної реабілітації хворих з доброякісною гіперплазією передміхурової залози (ДГПЗ) та високим операційним ризиком, обгрунтувавши диференційований підхід до застосування селективної артеріальної емболізації (САЕ) та монополярної трансуретральної резекції передміхурової залози (ТУРПЗ).

Матеріали і методи. Досліджено шляхом аналізу ефективність та безпечність САЕ передміхурової залози (ПЗ) як методу лікування симптомів нижніх сечовивідних шляхів (СНСШ) у хворих з ДГПЗ та високим операційним ризиком у порівнянні з ТУРПЗ. Аналіз базувався на систематичному вивченні функціональних результатів та ускладнень у 33 хворих основної групи, яким виконали САЕ, та у 39 хворих порівняльної групи, яким виконали ТУРПЗ.

Результати. Хворі, яким виконали САЕ, не мали операційної травми, у них був низький ризик виникнення післяопераційних ускладнень, коротший післяопераційний період, покращились показники: Міжнародної шкали оцінки простатичних симптомів (IPSS) - на 47,8\%, шкали оцінки якості життя (QOL) - на 53,3\%, максимальної об'ємної швидкості струменя сечі $\left(\mathrm{Q}_{\mathrm{max}}\right)$ - на 58,4\% на фоні зменшення об’єму П3 на 28,6\% та об'єму залишкової сечі на 55,3\% протягом 24 міс спостереження, що є підставою вважати САЕ ПЗ ефективним та безпечним методом мініінвазивного лікування ДГПЗ у хворих з високим операційним ризиком. Після монополярної ТУРПЗ результати були подібні: покращення показників IPSS - на 50\%, QoL - на 65,1\%, Q ${ }_{\max }$ - на 59,2\%, зменшення об'єму П3 - на 31,6\% та об'єму залишкової сечі - на 64,6\%, але даний метод супроводжувався статистично білышою частотою післяопераційних ускладнень, що погіршувало рівень періопераційної безпеки.

Висновки. Результати дослідження засвідчили, що САЕ є ефективним та безпечним методом лікування хворих з ДГПЗ та високим операційним ризиком, за результативністю порівнянним з ТУРПЗ, але з меншим ризиком виникнення післяопераційних ускладнень. САЕ може бути методом вибору у хворих похилого віку з вираженою супутньою патологією, які мають протипоказання до стандартного оперативного втручання або утримуються від нього з інших причин.

ключові слова: доброякісна гіперплазія передміхурової залози; селективна артеріальна емболізація; мініінвазивне лікування. Abstract

Objective. To improve the results of surgical rehabilitation of patients with benign prostatic hyperplasia (BPH) and high operative risk, substantiating a differentiated approach for application of selective arterial embolization (SAE) and monopolar transurethral prostatic resection (TUPR).

Materials and methods. The efficacy and safety of a prostatic SAE performance, as a method of treatment of the lower urinary ways in patients with benign prostatic hyperplasia (BPH) and high operative risk, comparing with TUPR, was investigated in the analysis way. The analysis was based on systematic studying of functional results and complications in 33 patients of the main group, to whom a SAE was performed and in 39 patients of a comparative group, to whom a TUPR was done.

Results. The patients, to whom SAE was performed, did not have operative trauma, they have got a low risk of postoperative morbidity occurrence, as well as a shorter postoperative period and the indices improved: the International Prostatic Symptoms Scales (IPSS) - by $47.8 \%$, the scales for the quality of life estimation (QoL) - by $53.3 \%$, of maximal voluminous of the urine flow $\left(\mathrm{Q}_{\max }\right)$ - by $58.4 \%$ on background of the prostatic volume reduction by $28.6 \%$ and the residual urine volume by $55.3 \%$ during 24 mo of follow-up, confirming the thesis, that prostatic SAE constitutes an effective and safe method of miniinvasive treatment of BPH in patients with high operative risk. After monopolar TUPR the results were similar: the IPSS indices improvement - by $50 \%$, QoL - by $65.1 \%, \mathrm{Q}_{\max }$ - by $59.2 \%$, the prostatic volume reduction - by $31.6 \%$ and of the residual urine volume - by $64.6 \%$, but this method was accompanied by statistically enhanced morbidity rate, degrading the perioperative safety level.

Conclusion. The investigation results have witnessed, that SAE constitutes an effective and secure method of treatment in patients with $\mathrm{BPH}$ and high operative risk, giving equal result with TUPR, but with less risk for postoperative morbidity occurrence. SAE may constitute a method of choice in elderly patients with severe concurrent diseases, who owe contraindications for a standard operative intervention or rejected its performance due to other causes.

Keywords: benign prostatic hyperplasia; selective arterial embolization; miniinvasive treatment. 
За даними Європейської асоціації урологів (САУ), ДГПЗ $є$ одним із найбільш розповсюджених захворювань чоловіків похилого віку, що може спричинити виникнення СНСШ. 3 огляду на зміну демографічної ситуації та зростання чисельності чоловіків похилого віку у всіх прошарках суспільства, в майбутньому неминуче це захворювання набуде ширшого розповсюдження та становитиме одну з першорядних проблем для системи охорони здоров'я.

Згідно з даними системного огляду та мета-аналізу S.W.H. Lee та співавторів, який охоплює 31 дослідження у 25 країнах світу, глобальна розповсюдженість ДГПЗ серед чоловічого населення становить 26,2\%, тобто 1 із 4 чоловіків у світі має або матиме це захворювання протягом життя [1]. За даними Інституту урології НАМН України, поширеність ДГПЗ в Україні в 2013 р. становила 1132,9 спостереження на 100000 дорослого чоловічого населення та 4434,5 спостереження на 100000 чоловічого населення віком старше за працездатний $[2,3]$.

У 2008 р. опубліковано перше повідомлення про лікування ДГПЗ методом артеріальної емболізації. В подальшому автори наводили отримані в короткотривалі та середньотривалі терміни спостереження багатообіцяючі результати лікування хворих з симптоматичною ДГПЗ, нечутливою до медикаментозної терапії, методом СЕА. Дані про значне покращення показників IPSS та $Q_{\max }$, зменшення об'єму ПЗ та об'єму залишкової сечі після застосування САЕ можна знайти в декількох дослідженнях [4 - 8].

Незважаючи на те, що емболізацію артерій ПЗ виконують невідкладно у разі післяопераційної кровотечі або іншого гострого стану, доцільність застосування цього методу у хворих з ДГПЗ потребує додаткових досліджень перш ніж включити його в клінічну практику як планове оперативне втручання. Також необхідно підтвердити безпечність вказаного хірургічного лікування шляхом контролю та реєстрації всіх його побічних ефектів та ускладнень.

Мета дослідження: покращити результати хірургічної реабілітації хворих з ДГПЗ та високим операційним ризиком, обгрунтувавши диференційований підхід до застосування СЕА та монополярної ТУРПЗ.

\section{Матеріали і методи дослідження}

Проспективно вивчено результати обстеження та оперативного лікування 72 хворих з обструктивною фор- мою ДГПЗ у клініці урології Національного військовомедичного клінічного центру «Головний військовий клінічний госпіталь» та відділенні ендоваскулярної хірургії Національного інституту хірургії та трансплантології імені О. О. Шалімова за період з 2010 по 2015 р. В основній групі (33 хворих) застосовували САЕ ПЗ, у порівняльній (39 хворих) - монополярну ТУРПЗ. Усі хворі обох груп мали високий операційний ризик.

Вік хворих основної групи коливався в межах 56 - 87 років та становив у середньому $(75,18 \pm 8,16)$ року; показник IPSS дорівнював у середньому $(24,5 \pm 6,8)$ бала; QoL $(4,47 \pm 0,93)$ бала, $Q_{\max }-(7,7 \pm 3,4)$ мл/с; середній рівень онкомаркера PSA total - $(3,9 \pm 2,4)$ нг/мл; середній об'єм П3 - $(92,5 \pm 33,7)$ см$^{3}$; середній об'єм залишкової сечі $(94,6 \pm 64,8)$ мл.

Вік пацієнтів порівняльної групи коливався в межах 56 - 90 років та становив у середньому $(75,19 \pm 7,84)$ року; показник IPSS дорівнював у середньому $(22,4 \pm 5,5)$ бала; QoL - $(4,26 \pm 0,89)$ бала; $\mathrm{Q}_{\max }-(7,1 \pm 2,4)$ мл/с; середній рівень онкомаркера PSA total - $(4,26 \pm 0,89)$ нг/мл; середній об'єм П3 - (79,0 $\pm 17,0)$ см$^{3}$; середній об'єм залишкової сечі - $(93,1 \pm 69,7)$ мл.

Обидві групи хворих були порівнянні за всіма вказаними показниками (р > 0,05), за винятком об'єму ПЗ (р $<0,05)$, оскільки застосування САЕ у хворих з об'ємом ПЗ

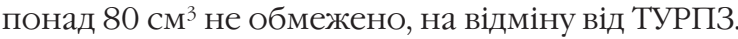

Переважна більшість хворих мала виражену супутню патологію, в тій чи іншій мірі субкомпенсовану на момент госпіталізації (табл. 1).

Супутня патологія обумовлювала високий ступінь операційного ризику. За шкалою Американської асоціації анестезіологів (American Society of Anaesthesiologists - ASA) рівень операційно-анестезіологічного ризику становив три бали та чотири бали у 51,4 та 48,6\% хворих 1-ї та 2-і груп відповідно.

Усі діагностичні та лікувальні ендоваскулярні маніпуляції хворим проводили, використовуючи ангіографічну систему Innova 2100 IQ.

Емболізацію виконували під місцевою анестезією з одного доступу, зазвичай з правої стегнової артерії Інтродюсер діаметром 5Fr вводили через праву загальну стегнову артерію, після чого катетер Cobra 2 (C2) 5 Fr Glidecath (Terumo) вводили в ліву внутрішню клубову артерію та ії переднє розгалуження. Встановивши катетер

\begin{tabular}{|c|c|c|c|c|}
\hline \multirow{3}{*}{ Супутні захворювання } & \multicolumn{4}{|c|}{ Групи хворих } \\
\hline & \multicolumn{2}{|c|}{ основна $(n=33)$} & \multicolumn{2}{|c|}{ порівняльна (n=39) } \\
\hline & абс. & $\%$ & абс. & $\%$ \\
\hline Ішемічна хвороба серця II - III стадії & 33 & 100 & 38 & 97,4 \\
\hline Гіпертонічна хвороба II - III стадії & 32 & 96,9 & 38 & 97,4 \\
\hline Цукровий діабет 2-го типу & 8 & 24,2 & 10 & 25,6 \\
\hline Виразкова хвороба шлунка або дванадцятипалої кишки & 4 & 12,1 & 3 & 7,7 \\
\hline Інфаркт міокарда в анамнезі & 8 & 24,2 & 9 & 23,1 \\
\hline Наслідки гострого порушення мозкового кровообігу & 5 & 15,2 & 4 & 10,3 \\
\hline Бронхіальна астма & 4 & 12,1 & 3 & 7,7 \\
\hline Облітеруючий атеросклероз артерій таза та нижніх кінцівок & 3 & 9,1 & 6 & 15,4 \\
\hline Хвороба Паркінсона & 2 & 6,1 & 1 & 2,6 \\
\hline
\end{tabular}


у передньому розгалуженні лівої внутрішньої клубової артерії, виконували цифрову субтракційну ангіографію в лівій передній косій проекції (35) та краніально-каудальну ангуляцію $\left(10^{\circ}\right)$ для візуалізації анатомії артерій П3. Вводили 5 мл контрастної речовини зі швидкістю 3 мл/с, з'ясовуючи, з якої саме артерії відбувається кровопостачання ПЗ. Після цього судини ПЗ селективно катетеризували за допомогою 3Fr коаксіального мікрокатетера EmboCath Plus (infusion microcatheter, Франція) або Progreat $^{\mathrm{TM}}$ (Японія).

Для емболізації використовували сферичні тріс-акрилжелатинові мікросфери Embosphere ${ }^{\circ}$ Microspheres (Merit Medical Systems, Inc, США) або полівініл-алкогольні гідрогелеві емболізаційні мікросфери Bead Block ${ }^{\mathrm{TM}}$ (Device Technologies, Австралія).

Кінцевою метою емболізації було значне уповільнення або «стаз» кровотоку в судинах ПЗ з припиненням артеріального притоку та помутнінням (опацифікацією) ПЗ. Після емболізації виконували контрольну ангіографію з повільним введенням контрастної речовини для запобігання пошкодження артерій.

3 метою підвищення ефективності лікування хворих з ДГПЗ та високим операційним ризиком і розміром ПЗ понад $90 \mathrm{~cm}^{3}$, ускладненою кровотечею, ми розробили новий мініінвазивний спосіб (Пат. на корисну модель № 99242 від 25.05.2015 р. А 61В 17/00 ), який базується на виконанні емболізації артерій ПЗ під рентгенконтролем та відрізняється тим, що суперселективну емболізацію судин ПЗ виконують через мікросудинні катетери з використанням як емболізату саме сферичних тріс-акрилжелатинових мікросфер «Embosphere» до повної обтурації просвіту судин.

\section{Результати}

Ми оцінювали ефективність та безпечність САЕ ПЗ як методу лікування СНСШ у хворих із ДГПЗ та високим операційним ризиком у порівнянні з ТУРПЗ. Аналіз базувався на клінічному спостереженні та систематичному вивченні показників об'єму П3, об'єму залишкової сечі, $\mathrm{Q}_{\max }$, IPSS та QOL починаючи з передопераційного періоду і через 1, 2, 6, 12 та 24 міс після операції, а також ускладнень, що виникли в основній та порівняльній групах хворих.

За допомогою порівняльного аналізу динаміки показників хворих основної та порівняльної груп виявлені певні закономірності. Більш швидку редукцію середнього об'єму ПЗ констатували через 1 міс після ТУРПЗ. Статистично достовірне ( $<$ < 0,05) зменшення об'єму ПЗ на 28,5 см 3 (36,1\%) відбулося протягом першого місяця після ТУРП3, в той час як після САЕ статистично достовірне $(\mathrm{p}<0,05)$ зменшення об'єму ПЗ на 30 см 32 (32,4\%) спостерігали лише на 6-му міс. Через 24 міс за цим показником групи суттево не відрізнялись: зменшення на 25 см³ $^{3}(31,6 \%)-$ після ТУРПЗ та на 25,9 см³ (28,6\%) - після САЕ (р > 0,05).

Аналіз динаміки показників середнього об'єму залишкової сечі в обох групах виявив значне їх покращення у порівняльній групі через 1 міс після операції - зменшення на 54,8 мл, а після 3-го міс статистично достовірних змін показників середнього об'єму залишкової сечі не фіксували до кінця періоду спостереження. В основній гру-

\begin{tabular}{|c|c|c|c|c|}
\hline Таблиця 2. & \multicolumn{4}{|c|}{$\begin{array}{l}\text { Розподіл хворих з ДГпз за } \\
\text { ступенем тяжкості ускладнень, } \\
\text { визначеним за класифікацією } \\
\text { Clavien-Dindo, залежно від методу } \\
\text { xірургічного втручання }\end{array}$} \\
\hline \multirow{3}{*}{$\begin{array}{c}\text { Ступінь } \\
\text { тяжкості } \\
\text { ускладнення }\end{array}$} & \multicolumn{4}{|c|}{ Групи хворих } \\
\hline & \multicolumn{2}{|c|}{ основна $(n=33)$} & \multicolumn{2}{|c|}{ порівняльна ( $\mathrm{n}=39$} \\
\hline & абс. & $\%$ & абс. & $\%$ \\
\hline 1 & 5 & 15,2 & - & - \\
\hline II & 8 & 24,2 & 19 & 48,7 \\
\hline III & - & - & 5 & 12,8 \\
\hline IV & - & - & 3 & 7,7 \\
\hline Всього ... & 13 & 39,4 & 27 & 69,2 \\
\hline
\end{tabular}

пі спостерігали більш повільне статистично достовірне зменшення об'єму залишкової сечі, яке на 3-му міс становило 17,2 мл. У подальшому цей показник зберігав позитивну динаміку. На 24-му міс за вказаним показником статистично значущої різниці між групами не було (p > 0,05): $(42,3 \pm 28,2)$ мл $(55,3 \%)$ - після САЕ та $(33,0 \pm 37,4)$ мл (64,6\%) - після ТУРПЗ.

Показники IPSS та QOL протягом усього періоду спостереження демонстрували статистично достовірне покращення в обох групах: в основній групі IPSS зменшився на 11,7 бала (47,8\%) (p < 0,05), QoL - на 2,4 бала (53,3\%) (p < 0,05), у порівняльній - на 11,2 бала (50\%) (p < 0,05) та на 2,8 бала $(65,1 \%)(\mathrm{p}<0,05)$ відповідно за 24 міс. Статистично значущої різниці між середніми значеннями цих показників в обох групах не виявлено. Через 24 міс після операції IPSS становив у середньому $(12,8 \pm 4,0)$ бала - в основній та $(11,2 \pm 3,4)$ бала - у порівняльній групі, QoL - у середньому $(2,1 \pm 0,8)$ та $(1,5 \pm 0,6)$ бала відповідно.

Показники $\mathrm{Q}_{\max }$ в динаміці в обох групах демонстрували істотне покращення у порівнянні з передопераційним рівнем: збільшення від $(7,7 \pm 3,4)$ до $(12,2 \pm 2,4)$ мл/с - в основній групі $(\mathrm{p}<0,05)$ та від $(7,1 \pm 2,4)$ до $(11,3 \pm 2,0)$ мл/с - у порівняльній групі ( $<$ 0,05) на 24-му міс, що становило відповідно 58,4 та 59,2\%.

Динаміка показників середнього рівня PSA total в обох групах вказувала на їх підвищення на 0,7 нг/мл через 1 міс після САЕ, проте ця різниця була статистично недостовірна ( $>$ > 0,05). Подальше спостереження за цим показником підтвердило, що він не мав достовірних відхилень.

Тривалість післяопераційного лікування суттєво відрізнялась між групами: $(3,76 \pm 2,05)$ ліжко-дня - в основній та $(5,56 \pm 2,83)$ ліжко-дня - у порівняльній групі. Достовірної різниці у тривалості знаходження уретрального катетера між групами не зареєстровано: $(2,45 \pm 2,56)$ дня - в основній та $(2,44 \pm 1,12)$ дня - у порівняльній групі.

Серед післяопераційних ускладнень у групі хворих, яким виконали ТУРПЗ, спостерігали: сечоміхурову кровотечу $-17,9 \%$ спостережень, загострення хронічного пієлонефриту - 12,8\%, гостру затримку сечі - 9,1\%, нетримання сечі - 10,3\%, звуження сечовипускного каналу - 7,7\%, гострий епідидиміт - 7,7\%, гострий коронарний синдром - 5,1\%, ТУР-синдром - 2,6\%.

Серед післяопераційних ускладнень у групі хворих, яким виконали САЕ, спостерігали: больовий синдром у промежині - 15,5\% спостережень, уретрорагію - 12,1\%, 


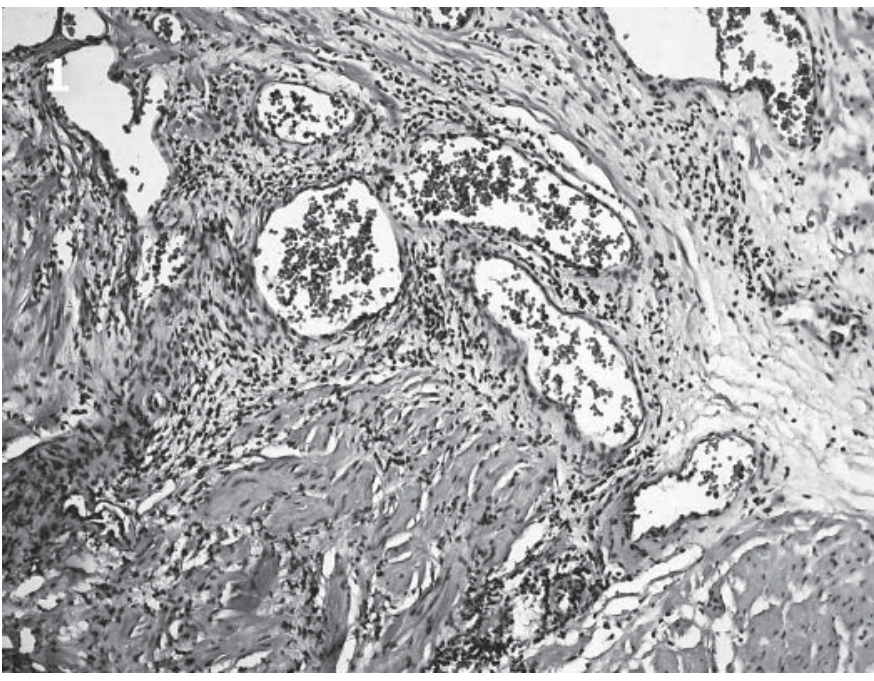

Puc. 1.

Повнокровні судини з фіброзом та гіалінозом у прилегліи стромі Пз

інтоксикаційний синдром - 6,1\%, нецільову емболізацію - 3,0\%, гостру затримку сечі - 3,0\%.

Проаналізувавши ускладнення післяопераційного періоду у пацієнтів обох досліджуваних груп за удосконаленою класифікацією Clavien-Dindo (2004), ми виявили певні закономірності (табл. 2). Зокрема, у порівняльній групі зареєстровано 27 (69,2\%) ускладнень, із них 19 (48,7\%) віднесено до II ступеня, а саме: сечоміхурову кровотечу - у 7 (17,9\%) хворих, загострення хронічного пієлонефриту - у 5 (12,8\%), гострий епідидиміт - у 3 (7,7\%), нетримання сечі у віддаленому післяопераційному періоді - у 4 (10,3\%). У 5 (12,8\%) хворих констатували ускладнення III ступеня, а саме: у 2 (5,1\%) - гостру затримку сечі в ранньому післяопераційному періоді, з приводу якої виконали повторну трансуретральну резекцію під спинномозковою анестезією, у 3 (7,7\%) - звуження сечовипускного каналу у віддаленому післяопераційному періоді, з приводу чого виконали оптичну лазерну уретротомію. Ускладнення IV ступеня спостерігали у 3 (7,7\%) хворих: у 1 (2,6\%) - ТУР-синдром та у 2 (5,1\%) - гострий коронарний синдром, у зв'язку з чим хворі продовжили лікування у відділенні інтенсивної терапії.

В основній групі зареєстровано менше ускладнень - 13 $(39,4 \%)$. У 5 (15,2\%) хворих був больовий синдром у промежині, який віднесено до І ступеня, цим хворим додатково призначали знеболюючі. У 8 (24,2\%) хворих діагностували ускладнення II ступеня, а саме: уретрорагію - у 4 $(12,1 \%) ;$ інтоксикаційний синдром - у 2 (6,1\%), у зв'язку 3 чим додатково призначали антибіотики; нецільову емболізацію - у 1 (3,0\%), для усунення якої проводили інфузію кристалоїдів та призначали антигістамінні препарати, та гостру затримку сечі, яку вилікували консервативними заходами - у 1 (3,0\%). Ускладнень III та IV ступеня в основній групі хворих зареєстровано не було.

Неускладненим перебіг післяопераційного періоду був у 20 (60,6\%) хворих основної та у 12 (30,8\%) - порівняльної групи.

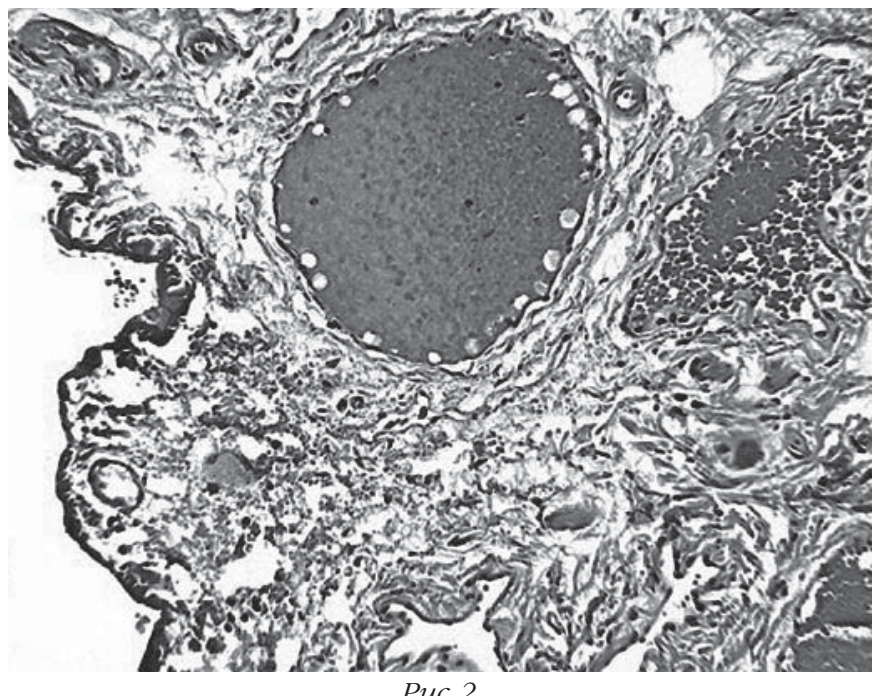

Puc. 2 .

Атрофія епітелію залоз, здебільшого представленого сплощеним епітелієм, клітини з вузькою базофільною цитоплазиою; виражений фіброз строми; хронічна запальна реакиія.

Таким чином, білыша частота ускладнень (69,2\%) після ТУРПЗ, ніж після САЕ (39,4\%), та їх тяжкість (ускладнення III, IV ступеня після ТУРПЗ виникли у 20,5\% хворих, тоді як ускладнень III, IV ступеня після CAE не констатували) дають підстави зробити висновок про більшу безпечність САЕ у порівнянні з ТУРПЗ.

\section{Обговорення}

На основі проведеного порівняльного аналізу результатів лікування хворих з ДГПЗ та високим операційним ризиком можна зробити висновок про порівнянну ефективність ТУРПЗ та САЕ. Більш швидка редукція об'єму ПЗ та об'єму залишкової сечі у порівняльній групі обумовлена технічними особливостями оперативного втручання, але це не дає переваги у клінічних показниках, на що вказує майже ідентична динаміка змін показників IPSS, QOL та $\mathrm{Q}_{\max }$ в обох групах протягом подальшого спостереження починаючи із 6 міс.

Тривалість післяопераційного лікування статистично достовірно відрізнялась між групами та була достовірно меншою в основній групі, що пов'язано з меншою частотою післяопераційних ускладнень та використанням для знеболювання місцевої анестезії.

САЕ була технічно успішною у 93,9\% хворих. У 2 (6,1\%) хворих через виражені атеросклеротичні зміни та звивистість артерій малого таза виконати оперативне втручання не вдалося. Покращити показник технічної успішності можливо шляхом ретельного передопераційного обстеження хворих та виконання комп'ютерної томографії з ангіографією малого таза у разі сумнівів. ТУРПЗ була технічно успішною у 100\% хворих, що обумовлено меншою технічною складністю та білышим досвідом виконання даного оперативного втручання.

Із 39 хворих, яким виконали ТУРП3, у 6 (15,4\%) протягом періоду дослідження не відбувалося достовірного покращення показників IPSS та QoL, незважаючи на статистично підтверджене достовірне покращення об'єктивних 
показників: збільшення максимальної швидкості сечовипускання, зменшення об'єму залишкової сечі та об'єму ПЗ. У всіх без винятку хворих, яким виконали САЕ, спостерігали клінічне покращення в тій чи іншій мірі, що вказує на 100\% клінічну успішність оперативного втручання.

У хворих порівняльної групи швидше, ніж в основній групі, зменшувався об'єм ПЗ та об'єм залишкової сечі на 1-му та 3-му міс спостереження. Це можна пояснити тим, що САЕ, на відміну від ТУРПЗ, не властивий безпосередньо аблятивний ефект. Методика САЕ спрямована на припинення артеріального кровотоку у тканині ПЗ, внаслідок чого розвивається ішемічний некроз тканини ПЗ 3 подальшим поступовим зменшенням об'єму ПЗ, що може тривати від кількох тижнів до кількох місяців.

Для вивчення впливу емболізуючого агента на тканину ПЗ, встановлення ступеня некротичних змін внаслідок припинення кровотоку ми провели гістологічне дослідження матеріалу, отриманого під час виконання ТУРПЗ у 2 хворих, яким раніше була виконана СAE, біопсійного матеріалу 1 хворого $з$ підвищеним PSA total у післяопераційному періоді та аутопсійного матеріалу ПЗ 1 хворого після попередньо виконаної САЕ.

Матеріал ПЗ був представлений сполучною тканиною, фібромускулярною стромою та скупченнями тубулоальвеолярних залоз, частково вкритих двохрядним, високим, світлим, циліндричним епітелієм з папілярною та псевдопапілярною складчастістю. Спостерігали дифузну та вогнищеву хронічну запальну реакцію у стромі, акцентування запалення навколо судин, вогнищеву атрофію епітелію залоз із ділянками кістозного перетворення. Частина судин була повнокровною, частина містила тромби (рис. 1).

Поряд з тим відмічали розростання сполучної тканини у вигляді фіброзу тканини ПЗ (рис. 2). Враховуючи термін взяття матеріалу, макрофагальної реакції не спостерігали. Запалення було представлено лімфоплазмоцитарним інфільтратом з поодинокими еозинофілами. Емболізуючі мікросфери в матеріалі ідентифіковані не були. Даних за інтраепітеліальну неоплазію або аденокарциному не отримано.

Отже, результати гістологічного дослідження тканини П3, отриманої у хворих, яким раніше виконали САЕ, свідчать про переважання неспецифічних запальних та фіброзних змін з периваскулярною локалізацією. Отримані дані підтверджують безпечність та ефективність методики САЕ при ДГПЗ, яка дає змогу уникати помилкових гістологічних висновків та підвищити можливості диференціальної діагностики хронічної гранулематозної реакції.

Результати нашого дослідження засвідчують, що САЕ може бути методом вибору для хворих похилого віку 3 вираженою супутньою патологією, які мають протипоказання до стандартного оперативного втручання або утримуються від нього з інших причин.

\section{Висновки}

1. Встановлено, що виражена супутня патологія з боку серцево-судинної, нервової, ендокринної та легеневої систем, а також шлунка та кишечника обумовлює високий ступінь операційного ризику у хворих похилого віку.

2. Наявність у хворих з ДГПЗ тяжкої серцево-судинної, дихальної та ендокринної патології, штучного водія ритму, анатомічно «вузького» та «довгого» сечовипускного каналу, прийом антикоагулянтів, об'єм ПЗ, що перевищує 100 см³ $^{3}$ бажання зберегти статеву функцію і безпосередньо природну еякуляцію та потреба у виконанні спинномозкової анестезії обмежують можливості застосування монополярної ТУРПЗ. Відсутність диференційованого підходу до застосування мініінвазивних методів лікування СНСШ у хворих з високим операційним ризиком та надання пріоритету виконанню ТУРПЗ призводять до незадовільних результатів лікування.

3. САЕ ПЗ $є$ високоефективним та безпечним методом, що забезпечує найбільш сприятливі умови для відновлення функції нижніх сечових шляхів, покращення показників IPSS, QoL, $Q_{\max }$, зменшення об'єму залишкової сечі та об'єму ПЗ, низький ризик виникнення післяопераційних ускладнень, коротший період післяопераційного лікування у порівнянні з монополярною ТУРПЗ.

\section{References}

1. Lee SWH, Chan EMC, Lai YK. The global burden of lower urinary tract symptoms suggestive of benign prostatic hyperplasia: A systematic review and meta-analysis. Scientific reports. [Internet]. 2017;7(1): 7984. Available from: https://www.nature.com/articles/s41598-017-06628-8 [Accessed 11 Aug 2017]. doi:10.1038/s41598-017-06628-8.

2. Vozianov SO, Saidakova NO, Startseva LM. Stan ta perspektyvy rozvytku urolohichnoi sluzhby v Ukraini. Urolohiia. 2013;17(3): 89-95. [In Ukrainian].

3. Saidakova NO, Startseva LM, Kravchuk NH. Osnovni pokaznyky urolohichnoi dopomohy v Ukraini za 2013-14 roky. Kyiv: Vidomche vydannia; 2015. 205 p. [In Ukrainian].

4. Bilhim T, Pisco J, Pinheiro LC, Tinto HR, Fernandes L, et al. Does polyvinyl alcohol particle size change the outcome of prostatic arterial embolization for benign prostatic hyperplasia? Results from a single-center randomized prospective study. Journal of Vascular and Interventional Radiology. 2013;24(11): 1595-602. doi: 10.1016/j.jvir.2013.06.003.

5. Carnevale FC, Antunes AA. Prostatic artery embolization for enlarged prostates due to benign prostatic hyperplasia. How I do it. Cardiovascular and interventional radiology. 2013;36(6): 1452-63. doi: 10.1007/ s00270-013-0680-5.

6. Kurbatov D, Russo GI, Lepetukhin A, Dubsky S, Sitkin I, et al. Prostatic artery embolization for prostate volume greater than $80 \mathrm{~cm} 3$ : results from a single-center prospective study. Urology. 2014;84(2): 400-4. doi: 10.1016/j.urology.2014.04.028.

7. Pisco JM, Tinto HR, Pinheir, LC, Bilhim T, Duarte M, et al. Embolisation of prostatic arteries as treatment of moderate to severe lower urinary symptoms (LUTS) secondary to benign hyperplasia: results of shortand mid-term follow-up. European radiology. 2013;23(0): 2561-72. doi: 10.1007/s00330-012-2714-9.

8. Tinto HR, Pisco JM, Bilhim T, Duarte M, Fernandes L, et al. Prostatic artery embolization in the treatment of benign prostatic hyperplasia: short and medium follow-up. Techniques in vascular and interventional radiology2012;15(4): 290-3. doi: 10.1053/j.tvir.2012.09.005. 